УДК 373.3.015.31

DOI: $10.15330 /$ esu. $17.352-358$
Юлія Мичка-Левченко,

аспірант, Національний університет

"Львівська політехніка" (м. Львів, Україна)

Yuliia Mychka-Levchenko,

Post-graduate student,

Lviv Polytechnic National University

(Lviv, Ukraine)

marusynetsm@ukr.net

\title{
РОЗВИТОК ХУДОЖНЬОГО СМАКУ УЧНІВ ПОЧАТКОВОЇ ШКОЛИ ЗАСОБАМИ НАВЧАЛЬНОГО МЕДІА-КОМПЛЕКСУ: ТЕОРЕТИКО-МЕТОДИЧНІ ПІДХОДИ
}

\section{DEVELOPMENT OF ARTISTIC TASTE OF ELEMENTARY SCHOOL PUPILS BY MEANS OF EDUCATIONAL MEDIA-COMPLEX: THEORETICAL AND METHODICAL APPROACHES}

У статті зроблено спробу показати роль мультимедійних засобів навчання для педагогіки образотворення, поліхудожнього вихования иколярів, на противагу традиційним. Окреслено основне завдання иколи - формування інформаційної культури сучасних иколярів, отримання ними найрізноманітнімої інформації, ефективний засіб підвищення інтересу до навчання, мотивачії, наочності, науковості тоцо. Програмиий засіб орієнтований на сучасні форми навчання із забезпеченням традииійних та інноваційних підходів до навчання в повній відповідності з документами, ио регламентують зміст освіти. Запропонований комплекс розиирюе $i$ покраиуе інформаційний, наочний, методичний арсенал учителя образотворчого мистечтва незалежно від рівня професійної кваліфікачії та досвіду.

Ключові слова: учні, початкова икола, медіа, теоретичні підходи, методики розвитку художнього смаку, навчальний медіа-комплекс, образотворче мистечтво

The article presents aspects such as multimedia learning tools that present the latest technological capabilities in art pedagogy for semi-artistic student education.

The cultural, environmental, axiological and creative methodological approaches are presented the general directions of development of artistic tastes of primary school pupils. The conceptual approach is played a great role between theoretical approaches and methods of developing art pupils' preferences. The educational media complex has also a huge role in this process.

The integrative approach which combining theoretical posibilities with instrumental is played the chief role in the article. Thanks for this approach it is possible to generalize, systematize and holistically presence and development of artistic tastes of the primary school pupils.

Possibilities of using the pedagogical software tools "Fine Arts" which aimed at achieving the following pedagogical goals are presented: support of collective, group, paired and individual forms of teaching in the conditions of the classroom-lesson system of organization of the educational process; creating comfortable computer support for traditional and innovative learning technologies; activation of pupils' cognitive interest; providing the differentiated and integrated approaches to the study of the subject; structuring and motivation of learning content; extension of educational art competences and etc.

The software is focused on modern forms of education, providing traditional and innovative approaches to learning in full accordance with the documents include the content of education. The proposed complex incredibly rich set of data the information, visual, methodological knowledge of the art teacher, regardless of the level of professional qualification and experience.

Key words: pupils, primary school, media, theoretical approaches, methods of development of artistic tastes, educational media complex, fine arts. 
Актуальність проблеми дослідження. Сьогодні надзвичайно актуальним $\epsilon$ питання формування естетичної культури учнів. Її рівень визначає стан вихованості людей у суспільному житті, їхнє гуманістичне ставлення до життя. Формування художнього смаку передусім полягає в зовнішньому та внутрішньому перетворенні особистості як цінності, естетичної й духовно-моральної. Державні стандарти загальної середньої освіти пропонують дисципліни естетичного циклу, що формують в учнів систему естетичних цінностей як інтегральної основи світогляду, здатності до творчої самореалізації, виховання потреби в духовному самовдосконаленні [1]. У вирішенні проблеми естетичного виховання учнів початкової школи неоціненне значення мають не тільки суспільні духовні надбання, художньо-естетичні й історико-педагогічні звичаї нашого народу, практично невичерпні можливості сучасних медіа для викладу і подачі учням навчального матеріалу.

Ми вважаємо, що особливу увагу варто приділити розвитку художнього смаку учнів-початківців, позаяк основи естетичних світогляду й почуттів у малечі закладають власне вчителі молодших класів. Дослідивши питання розвитку художніх уподобань учнів початкової школи, маємо підстави вважати, що сьогодні вкрай актуально теоретично обгрунтувати концептуальні основи розвитку художніх уподобань учнів засобами навчального медіа-комплексу, уточнити поняття естетичного виховання й розробки реальних методик зазначеними засобами.

Активний розвиток та впровадження інформаційних технологій у різні сфери життя, в тому числі в освіту, одним з основних завдань перед школою ставлять формування інформаційної культури сучасних школярів. Комп'ютерні технології це потужний інструмент для отримання дитиною найрізноманітнішої інформації, ефективний засіб підвищення інтересу до навчання, а також мотивації, наочності, науковості тощо.

Мета загальної образотворчої освіти в школі полягає в особистісному розвитку учнів і збагаченні їхнього емоційно-естетичного досвіду під час сприймання навколишнього світу і художньо-практичній діяльності, інтерпретації та оцінювання творів образотворчого мистецтва, а також у формуванні ціннісних орієнтирів, потреби в творчій самореалізації та духовно-естетичному самовдосконаленні.

Мета статті: обгрунтування методологічних підходів до розвитку художніх уподобань учнів початкової школи за допомогою засобів навчального медіакомплексу.

Виклад основного матеріалу. Новітніми логікою й методологією науки передбачено враховувати також позанаукові (історичні, психологічні, художні) чинники. Ба більше, сьогодні очевидно, що, окрім двох загальновідомих рівнів пізнання, теоретичного й емпіричного, абсолютно виправданий образний - рівень пізнання як перехідний і проміжний між ними.

Естетична оцінка означує щабель довершеності світу предметів, вираженого у відповідних кількісних зв'язках. Відчайдушно сповідуючи важливість навчати прекрасному, треба наголосити, що не завжди високоосвічена людина свої знання застосовує для добра. Знання стають активними в боротьбі за ідеї, розподіляючи ворожі аспекти - з одного боку, красу й добро, з іншого - потворність і зло. Тобто беззмістовно в педагогіці протиставляти утилітарність i красу, практицизм i естетику. Науковці дедалі частіше переконані, що раціональному не має бути протиставлене емоційне. Адже їхнє поєднання, навпаки, запалює полум'я творчості й естетики. Саме завдяки розмаїттю естетичних $\mathrm{i}$ художніх засобів педагог трансформує наукову істину. Краса, яку вчитель доносить дітям на уроці, набуває 
конкретно-чуттєвої форми, коли процес навчання характерний двома напрямами: пізнанням і насолодою.

Ми вважаємо, що основні теоретичні підходи до розвитку художнього смаку учнів початкової иколи - культурологічний, середовищний, аксіологічний, творчий. Проаналізуємо зазначені підходи у контексті проблеми дослідження.

Загальна увага суспільства сьогодні прикута до проблеми формування культури вчителя. Попри те, що повну відповідальність за виховання молоді ніколи не брав на себе вчитель, інтелектуальний розвиток учнів сьогодні надзвичайно всіх хвилює. Прикро, та впродовж останнього десятиріччя освітній процес відокремився від духовності індивіда. Країна потребує духовного відродження, шляхом до якого є культурний розвиток особистості молоді. Тому процес формування естетичного розвитку має передбачати знання й бачення закономірностей мистецтва, побудови та сприйняття творів мистецтва, механізмів дії культури.

На думку Т. Мороза "застосування загальнокультурної складової як засобу естетичного виховання допоможе становленню учня початкової школи, збагачуючи його національними й універсальними цінностями рідної й інших культур; дасть змогу сформувати духовну складову особистості, виховати іiі морально-естетичні цінності, враховуючи загальнолюдське, конкретно історичне й національне; посилити гуманітарність сутності освіти, пов'язану з неоднозначністю феномена людського життя, що грунтується на гармонії у знаннях, почуттях і творчості” [4, с. 2].

Досліджуючи культурну цінність вітчизняного мистецтва в історичному вимірі, О.Рудницька акцентує на особистісній культурі, що охоплює низку знань як важливу складову культури, торуючи шлях до неї; розумінні ціннісного значення предметів культури, спроможності оцінювати їхні властивості 3 погляду тих чи інших ідеалів, побудову моделі діяльності, вибір стилю поведінки, прийнятих певною культурою. Унікальність національної художньої культури - у феномені культурного православ'я, архітектурних пам'ятках, в українському театрі, образотворчому й музичному мистецтві, вітчизняній освіті, в народних пісні й танці, в декоративно-ужитковому мистецтві тощо. “Світ мистецтва являє собою відкритий простір своєрідних культур, репрезентуючи розмаїття людського досвіду творчої діяльності. Кожна 3 них виражає самобутність національних традицій в їх взаємозв'язку 3 духовними надбанням Інших народів і дає можливість осягнути цілісну художню картину світу, уявити собі спільність людської цивілізації, в якій кристалізується внутрішнє багатство неповторних національних культур" [2, с. 3-4].

Культурно-освітнє середовище, в межах якого розміщений початковий освітній заклад, охоплює регіональний культурно-соціальний ареал, пов'язаний 3 історико-культурними й художньо-естетичними звичаями конкретного регіону, специфікою виховання й відношення до особистості [3]. Школа становить не лише частку культурного простору суспільства, а сама $\epsilon$ особливим культурним простором, що транслює знання й культурні цінності; осередком естетичної творчості, культурного обміну та спілкування у формі художньо-естетичного діалогу, духовним спрямуванням індивідуального впливу на учня. Для осередку естетичної творчості притаманні атмосфера емоційного насичення й естетичного сприйняття пізнавальної діяльності, креативне вирішення пізнавальних, науково-дослідних, художніх і комунікативних завдань.

Кожну особистість розвиває й формує те середовище, в якому вона перебуває. Хай там як, навчальне середовище повинно бути: виховним, розвивальним, інформативним, естетичним, гуманним, духовним, екологічним тощо. Одне 3 важливих 
завдань педагогічної діяльності - сформувати середовище, спроможне впливати на навчально-виховний процес та його результати. Середовищний підхід передбачає зарахування закладу освіти в навколишнє середовище і навпаки. Найскладніше й найфункціональніше навчально-виховне середовище освітнього закладу, що органічно поєднує дві основні функції: навчальну й виховну.

Культурно-освітнє середовище треба досліджувати в контексті його духовної сутності, тобто загального культурного розвитку учнів, ступеня розвитку їхніх цінностей, духовних потреб та зацікавлень. Отож, з-поміж низки освітніх завдань, одне $з$ важливих - збереження культурних надбань, ретельний відбір відповідного матеріалу для ефективного навчання й виховання нового покоління.

У теорії виховних систем мета, умова й результат середовища - особистість. Отож, проектування, виховання особистості необхідно досліджувати за середовищем. Середовище опосередковує шлях розвитку особистості, заломлює його свідомість (самосвідомість) і поведінку різними можливостями, що гарантують ту чи іншу якість життя.

Аксіоматика й походження середовищного підходу “у вихованні прояснює основні ідеї, на яких базується практика реалізації цього підходу, що суттєво допомагає нам ще раз переконатися в інтеграційності освітнього середовища, зокрема, виховної системи" [7, с. 42]. Новим аспектом дослідження проблеми є й ідея неодмінного забезпечення цілісного виховного простору, тобто планомірного опанування школою навколишнього середовища, яке забезпечить використання можливостей системи виховання як відкритої.

У нинішні часи розбудови вітчизняної школи надзвичайно важливе питання формування духовності, морально-естетичної культури учнів, утвердження людини як найвищої суспільної цінності. Аби молодь могла успішно опанувати загальнолюдські, етичні, художні й естетичні життєві й культурні цінності, необхідно посилювати культурологічні й гуманістичні напрями освіти, оновлювати сутність i якість підготовки майбутніх педагогів до естетичного розвитку учнів на засадах гуманізації, власної зорієнтованості, творчості. Навчання й виховання ціннісними засобами - "це аксіологія навчання й виховання, що грунтується на впливові справжніх вартостей життя і культури на особу вихованця, іiі становлення та розвиток. Естетичні цінності є основою життєвих орієнтацій особи, бо критерії, які грунтуються на виявленні прекрасного й піднесеного в людині, найчастіше діють не окремо, а в поєднанні з моральними та соціальними принципами й нормами" [5, с. 11]. Отож, мистецтво створює власну систему суспільних цінностей, що сповідує норми моралі й естетичні ідеали. Зазвичай розвиток такої системи цінностей перебуває попереду реального рівня духовно-практичного опанування людьми природи, позаяк мистецька образність еволюціонує стрімкіше за норми поведінки й психології людей.

Творчість пронизує всі аспекти естетичного опанування художніх, естетичних цінностей, різних видів мистецтва: естетичні сприйняття, оцінка, судження. Завданням естетичного виховання також $є$ формування в кожної особистості здібності до творчості за "законами краси". Тож основний чинник естетичного виховання учнів їхня участь у різних видах художньо-естетичної творчості. Засобами естетичного виховання слугують також естетичні освіта й художнє навчання. Завдяки комплексному втіленню всіх засобів і методів естетичного виховання естетична культура особистості безумовно зростає. 
Важливо також удосконалювати різноманітні форми естетичної свідомості, а саме: естетичні оцінки як особливі думки про предмети; естетичний ідеал як уявлення про естетичну довершеність життя людини; естетичний світогляд як сукупність ідей і думок.

Наступний крок - визначення концептуального підходу, - сполучної ланки методологічних і методичних підходів до розвитку художнього вподобання учнів завдяки навчальному медіа-комплексу. Це зокрема інтегративний підхід - поєднання методологічного з інструментальним, завдяки чому можливі узагальнення, систематизація й цілісне подання розмаїття аспектів розвитку художнього смаку учнівпочатківців.

Дослідник О. Федій вважає, що вплив науки й мистецтва на людину дещо схожий. Митець у своєму житті зауважує факти, зазначаючи, що як у науці, так і в мистецтві образ визначений особисто, це особове бачення Всесвіту, проникнення в його сутність. Розвиток образності в науці й мистецтві невід'ємний від історикокультурного стилю епохи. Естетична складова психолого-педагогічної підготовки педагога дуже важлива [6, с. 4]. Аби у фаховій діяльності використовувати засоби естетотерапії, сучасний педагог має володіти естетотерапевтичними знаннями, уміннями й навичками, почерпнутими 3 різних прилеглих до педагогіки наук: новітня філософія освіти, культурологія, естетика, мистецька освіта, психологія й психотерапія та ін.

Для практичного втілення естетичного виховання були застосовані авторські методики, представлені нижче.

Урок образотворчого мистецтва в загальноосвітньому навчальному закладі спрямований на пізнання навколишнього світу засобами візуального мистецтва та розуміння учнями зв'язків образотворчого мистецтва 3 природним навколишнім світом, 3 іншими видами мистецтва, 3 культурним середовищем життєдіяльності людини.

Основними завданнями курсу є: формування уявлень про сутність, види та жанри образотворчого мистецтва, особливості художньо-образної мови, засвоєння основних художніх прийомів; відчуття, кольору, лінії, ритму, композиції, колориту та ін., безпосередньо у мистецькій діяльності; та через сприймання творів мистецтва; розвиток асоціативно-образного та просторового мислення, уяви, фантазії, пам'яті, художнього смаку і творчих здібностей; опанування вміннями та навичками в образотворчій діяльності; формування художньо-практичної компетентності; готовності використовувати отриманий досвід у самостійній творчій роботі; виховання духовних та моральних ціннісних орієнтирів у сфері образотворчого мистецтва; розуміння учнями зв'язків образотворчого мистецтва 3 іншими видами мистецтва, 3 природним і культурним середовищем життєдіяльності людини.

Саме на вирішення цих завдань спрямовані образотворчого мистецтва із застосуванням комп'ютерних технологій. Кожен із таких уроків є сукупністю малюнків, світлин, анімацій, відеофрагментів, текстових пояснень, звукового супроводу, зразкового виконання практичних робіт, правил 3 техніки безпеки, правил роботи 3 різноманітними матеріалами, підсумкових запитань тощо, які може використати педагог при проведенні заняття з застосуванням ППЗ.

Методикою проведення уроків образотворчого мистецтва передбачено гармонійне поєднання у структурі уроку різноманітних видів діяльності та видів мистецтва (література, музика, театр тощо). Мультимедійні засоби навчання відкривають нові технологічні можливості для педагогіки образотворення, унікальні 
можливості поліхудожнього виховання школярів, мають переваги порівняно 3 традиційним навчанням, допомагають поєднувати візуальні, музичні, театральні й інші види мистецтва

Педагогічний програмний засіб (ППЗ) “Образотворче мистецтво” розроблений відповідно до програми для загальноосвітніх навчальних закладів “Образотворче мистецтво” (1-4 класи) (авт. Л. Любарська, Л. Вовк). Програмний засіб орієнтований на сучасні форми навчання із забезпеченням традиційних та інноваційних підходів до навчання в повній відповідності 3 документами, що регламентують зміст освіти. Увесь курс складається з 35 уроків, що відповідає навчальній програмі. Кожен урок розкриває конкретну тему згідно навчальної програми та містить засоби для пояснення необхідної теми: малюнки, світлини, текст, анімації, аудіо- та відеофрагменти, зразкове виконання практичних робіт, правила роботи з різними матеріалами, особливості роботи в тій чи іншій техніці тощо. Для перевірки знань передбачено підсумкові заняття, запитання для самоконтролю та контролю. Окрім того, програмний засіб містить довідникову інформацію: довідку роботі з ППЗ, словник термінів і понять, іменний покажчик, правила роботи з матеріалами, правила техніки безпеки.

Використання ППЗ “Образотворче мистецтво" дає можливість досягнення наступних педагогічних цілей: підтримка колективних, групових, парних та індивідуальних форм навчання в умовах класно-урочної системи організації навчального процесу; створення комфортних умов комп'ютерної підтримки традиційних і новаторських технологій навчання; активізація пізнавального інтересу учнів; забезпечення диференційованого та інтегрованого підходів до вивчення предмету; структуризація та мотивація змісту навчання; розширення освітніх мистецьких компетенцій. ППЗ “Образотворче мистецтво” може бути використаний учителем (для підготовки та проведення уроку; проведення тестового контролю знань; створення власних уроків і редагування існуючих; проведення індивідуальних і факультативних занять) та учнем (для самостійного вивчення матеріалу, для підготовки до уроку, закріплення набутих знань тощо).

Висновки. Мультимедійні засоби навчання відкривають нові технологічні можливості для педагогіки образотворення, унікальні можливості поліхудожнього виховання школярів, мають переваги порівняно 3 традиційним навчанням, допомагають поєднувати візуальні, музичні, театральні й інші види мистецтва. Культурологічний, середовищний, аксіологічний i творчий теоретичні підходи формують загальні орієнтири вироблення художнього смаку учнів початкової школи. Концептуальний підхід, який пов'язує теоретичні підходи та розроблені методики інтегративний, а спеціальний - естетотерапевтичний. Для практичного втілення естетичного виховання були застосовані авторські методики, а саме: створення педагогічного програмного засобу “Образотворче мистецтво" для того, щоб синтезувати вербальну, візуальну, звукову та рухову інформацію, поєднувати абстрактно-логічні та предметно-образні форми наочності, підвищувати мотивацію навчання за рахунок єдності пізнання та розваги, емоційності та образності форми викладу навчального матеріалу, можливістю вибору вчителем та учнями темпу та послідовності діяльності, обсягу навчального матеріалу тощо. Використання ППЗ “Образотворче мистецтво” дає можливість досягнення таких педагогічних цілей як підтримка колективних, групових, парних та індивідуальних форм навчання в умовах класно-урочної системи організації навчального процесу; створення комфортних умов комп'ютерної підтримки традиційних і новаторських технологій 
навчання; активізація пізнавального інтересу учнів; забезпечення диференційованого та інтегрованого підходів до вивчення предмету; структуризація та мотивація змісту навчання; розширення освітніх мистецьких компетенцій тощо. Цей комплекс розширює методичний арсенал учителя образотворчого мистецтва незалежно від рівня професійної кваліфікації та досвіду. Подальшими напрямами дослідження вважаємо розроблення й реалізацію аналогічних методик для кожного класу початкової школи для формування художнього смаку учнів засобами навчального медіа-комплексу.

\section{Література}

1. Антонюк В. 3. Формування художнього смаку старших підлітків у процесі вивчення інформатики у загальноосвітній школі: автореф.дис. на здобуття наук. ступеня канд. пед. наук: спец. 13.00.07 "Теорія та методика виховання"/ В. 3. Антонюк. Херсон, 2008. 20c.

2. Іванова В. Л. Педагогічні умови організації діяльності дитячих центрів естетичного виховання: автореф. дис. на здобуття наук. ступеня канд. пед. наук: спец. 13.00.06 “Теорія та методика управління освітою" / В. Л. Іванова. К., 2003. 20 с.

3. Капська А. И. Основні закономірності художньо-естетичного виховання учнівської учнів / А. И. Капська // Нові технології виховання: 36. наук. ст. К., 1995. С.96-105.

4. Мороз Т. О. Загальнокультурна компонента як засіб естетичного виховання майбутніх учителів іноземної мови: автореф. дис. на здобуття наук. ступеня канд. пед. наук: спец. 13.00.07 “Теорія та методика виховання”/ Т. О. Мороз. Луганськ, 2007. 20с.

5. Савченко Н. С. Підготовка вчителя до формування естетичних орієнтацій молодших школярів на цінності народного мистецтва (в умовах позакласної діяльності): дис... канд. пед. наук: 13.00.04 / Наталія Сергіївна Савченко. - Кіровоград, 2000. 207 с.

6. Федій О. А. Підготовка студентів педагогічних інститутів до естетичного виховання дітей 6-7 років: дис... канд. пед. наук: 13.00.04 / Ольга Андріївна Федій. Полтава, 1995. 190 с.

7. Чернуха Н. М. Інтеграція виховних соціальних впливів суспільства у формуванні громадянськості учнівської учнів : дис. ... доктора пед. наук: 13.00 .05 / Надія Миколаївна Чернуха. Луганськ, 2007. 423c.

\section{References}

1. Antoniuk V. Z. Formuvannia khudozhnoho smaku starshykh pidlitkiv u protsesi vyvchennia informatyky u zahalnoosvitnii shkoli: avtoref.dys. na zdobuttia nauk. stupenia kand. ped. nauk: spets. 13.00.07 "Teoriia ta metodyka vykhovannia" / V. Z. Antoniuk. Kherson, 2008. 20s.

2. Ivanova V. L. Pedahohichni umovy orhanizatsii diialnosti dytiachykh tsentriv estetychnoho vykhovannia: avtoref. dys. na zdobuttia nauk. stupenia kand. ped. nauk: spets. 13.00.06 "Teoriia ta metodyka upravlinnia osvitoiu" / V. L. Ivanova. K., 2003. 20 s.

3. Kapska A. Y. Osnovni zakonomirnosti khudozhno-estetychnoho vykhovannia uchnivskoi uchniv / A. Y. Kapska // Novi tekhnolohii vykhovannia: 36. nauk. st. K., 1995. S.96-105.

4. Moroz T. O. Zahalnokulturna komponenta yak zasib estetychnoho vykhovannia maibutnikh uchyteliv inozemnoi movy: avtoref. dys. na zdobuttia nauk. stupenia kand. ped. nauk: spets. 13.00.07 "Teoriia ta metodyka vykhovannia"/ T. O. Moroz. Luhansk, 2007. 20s.

5. Savchenko N. S. Pidhotovka vchytelia do formuvannia estetychnykh oriientatsii molodshykh shkoliariv na tsinnosti narodnoho mystetstva (v umovakh pozaklasnoi diialnosti): dys... kand. ped. nauk: 13.00.04 / Nataliia Serhiivna Savchenko. - Kirovohrad, 2000. 207 s.

6. Fedii O. A. Pidhotovka studentiv pedahohichnykh instytu $\neg$ tiv do estetychnoho vykhovannia ditei 6-7 rokiv: dys... kand. ped. nauk: 13.00.04 / Olha Andriivna Fedii. Poltava, 1995. $190 \mathrm{~s}$.

7. Chernukha N. M. Intehratsiia vykhovnykh sotsialnykh vplyviv suspilstva $u$ formuvanni hromadianskosti uchnivskoi uchniv : dys. ... doktora ped. nauk: 13.00.05 / Nadiia Mykolaivna Chernukha. Luhansk, 2007. 423s. 